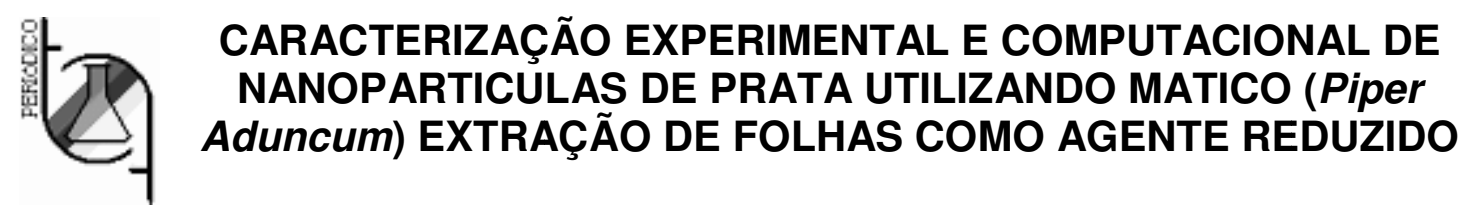

\title{
EXPERIMENTAL AND COMPUTATIONAL CHARACTERIZATION OF SILVER NANOPARTICLES USING MATICO (Piper aduncum) LEAVES EXTRACT AS REDUCING AGENT
}

\author{
SANTORUM, Nathaly ${ }^{1}$; FABARA, Andrea ${ }^{2}$; PILAQUINGA, Fernanda ${ }^{1,3}$; AMPUDIA, \\ Santiago ${ }^{1}$;JARA, Eliza ${ }^{1}$;MENESES, Lorena ${ }^{2 *}$ \\ ${ }^{1}$ Laboratory of Nanotechnology, Pontifical Catholic University of Ecuador, 12 de octubre 1076 Avenue, zip code \\ 170525, Quito-Ecuador. (Phone: +593 2 991700) \\ ${ }^{2}$ Laboratory of Computational Chemistry, Pontifical Catholic University of Ecuador, 12 de octubre 1076 Avenue, \\ zip code 170525, Quito-Ecuador. (Phone: +593 2 991700) \\ ${ }^{3}$ InstituteofMaterials Science of Sevilla, University of Sevilla, Prof. García González Street, zip code 41012, \\ Sevilla - Spain. (Phone: +34 954559765) \\ ${ }^{*}$ Corresponding author email: Immeneses@puce.edu.ec
}

Received 05 December 2017; received in revised form 14 December 2017; accepted 20 December 2017

\begin{abstract}
RESUMO
As nanopartículas de prata são reconhecidas para inúmeras aplicações físicas, biológicas e farmacêuticas. Neste estudo, as nanopartículas de prata foram sintetizadas com êxito pelo método de redução alternativa de química verde, usando extrato de folhas Matico (Piper aduncum). A caracterização foi realizada através da Espectroscopia Ultravioleta / Visível para estimar o tamanho da partícula; A morfologia e a composição elementar foram detectadas por microscopia eletrônica de varredura. O raio estimado foi medido por ScanningTransmissionElectronMicroscopy. A interação entre o extracto de folhas Matico com nanopartículas para determinar possíveis ingredientes ativos de redução foi monitorada por espectroscopia de infravermelho. O rendimento da reação foi determinado pela Espectroscopia de Absorção Atômica de Chama. A interação de clusters de nanopartículas de prata (3,5 e 6 átomos) com quercetina (uma molécula ativa das folhas maticas) foi estudada usando DensityFunctionalTheoryand Molecular Dynamics por Gaussian09 e Abalone. O tamanho de partícula foi $13,58 \pm 6,25 \mathrm{~nm}$. Verificou-se que as nanopartículas são quase esféricas com $7,2 \%$ de prata elementar e um rendimento de reação de $96,68 \%$. O cluster de 6 átomos de prata com quercetina demonstrou ser o complexo mais estável. As nanopartículas de prata sintetizadas apresentam estabilidade superior a 120 dias, confirmando que o extrato de folhas Matico é um agente redutor viável e verde. As nanopartículas de prata teriam propriedades de depuração muito boas porque a dinâmica molecular demonstrou que, ao longo de um certo período de tempo, o conjunto de prata ficou longe da quercetina.
\end{abstract}

Palavras-chave: nanopartículas de prata, Piper aduncum, interação computacional, quercetina.

\begin{abstract}
Silver nanoparticles are recognized for numerous physical, biological and pharmaceutical applications. In this study, silver nanoparticles were successfully synthesized by green chemistry alternative reduction method, using Matico (Piper aduncum) leaves extract. The characterization was performed through Ultraviolet/VisibleSpectroscopy to estimatethe particle size; morphology and elemental composition were detected by Scanning Electron Microscopy. Estimated radius was measured by Scanning Transmission Electron Microscopy. The interaction between Matico leaves extract with nanoparticles to determine potential reducing active ingredients was monitored by InfraredSpectroscopy. The reaction yield was determined by Flame Atomic Absorption Spectroscopy. The interaction of clusters of silver nanoparticles (3,5 and 6 atoms) with quercetin (an active molecule of the Matico leaves), was studiedusing Density Functional Theory and
\end{abstract}


Molecular Dynamics by Gaussian09 and Abalone programs. The particle size was $13.58 \pm 6.25 \mathrm{~nm}$. It was found that the nanoparticles are quasi-spherical with $7.2 \%$ of elemental silver and a reaction yield of $96.68 \%$. The cluster of 6 silver atoms with quercetin was proven to be the most stable complex. Synthesized silver nanoparticles display stability greater than 120 days, confirming that Matico leaves extract is a viable and green reducing agent.Silver nanoparticles would have very good clearance properties because molecular dynamics demonstrated that over a certain period of time, the silver cluster got far away from the quercetin.

Keywords: Silver nanoparticles, Piper aduncum, computational interaction, quercetin.

\section{INTRODUCTION}

Bionanoscience is a growing field that searches to establish enough knowledge about biomimicry processes to solve medical, biotechnological and pharmaceutical issues (Flores, 2014).

Silver nanoparticles (AgNPs) have unique optical, electrical and thermal properties. The present applications range from photovoltaics to biological and chemical sensors. Silver nanoparticles also present biological applications such as molecular diagnostics and photonic devices, and nanomedicinein drug delivery, imaging diagnostics and biosensing (Rongzhong et.al., 2013)

The AgNPs generate large interest in biomedical applications, due to their bactericide activity produced by the ease of entering in the cell membrane and different interactions with cellular organisms (Cruz, 2012). Early studies evidence wound healing acceleration in silver nanoparticles presence owing to inflammation decreasing effect, attributed to metalloproteinase (MMP) local activity reduction (Prabhu and Poulose, 2012).

However, it is important to study and have a good insight of the possible consequences of the use of AgNPs. Nanoparticles are being daily used, yet a concern raises due to the fact that their toxicitycan put human health at risk (Lewinski et.al., 2008).Thus, to develop new nanoparticles and continue their use and development more studies and evaluation have to be done. One of the possibilities to do so is the investigation of silver nanoparticles through quantum mechanics calculations.

AgNPs traditional synthesis methods were based on the Creigthon principle proposal, using as metallic precursor silver nitrate $\left(\mathrm{AgNO}_{3}\right)$ solution and sodium borohydride $\left(\mathrm{NaBH}_{4}\right)$ as reducing agent (Shakeel et al. 2016).

Some authors have been exploring alternative ways to obtain AgNPs, achieving biological conditions that reduce costs and wastes, suppress toxic reagents and allow for customizing particles shape and size. Among the synthesis candidates, plants, fungus and bacteria could be used (Prabhu and Poulose, 2012).

Matico (Piper aduncum), is a perennial specie from the Andean region of Equator, located between 3000 and 3700 meters above sea level. It owns wound healing, anti-inflamatory and antibacterial properties, attributed to active principles present in its leaves and branches. Essential oils have been identified, tannic acid, resins, tannins, alkaloids, saponins, flavonoids, terpenoids and bitter substances like maticin. The main wound healing component is proanthocyanidin, a tannin with a concentration of $5.7 \%$ in leaves (Sanín, 2015).

Quercetin, one of the principal components of this plantwas chosen to interact with the silver clusters, because in a previous study, coated silver nanoparticles with $P$. aduncum presented extraordinary healing properties (Santorum, 2017).

The goal of this paper is to analyze the viability of application of Matico ( $P$. aduncum) leaves extract as reducing agent to synthesize silver spherical nanoparticles, then characterize them by experimental methods and computationall yestablish quantitative structureactivity between the interactions of silver nanoparticles with biological molecules as quercetin in order to compare and prove the healing properties of the silver nanoparticles covered with quercetin.

\section{MATERIALS AND METHODS}

2.1. Matico ( $P$. aduncum) leaves extract 
preparation

Matico leaves were collected in Carapungo area, Pichincha-Ecuador. Different solvent concentrations were tested using water and ethanol mixes, with 25,50 and 75 water percentage to establish the optimum extract solvent.

Extract concoction was based on the procedures proposed by Hurtado (2015). The sample was washed, dried and triturated in order to weigh $1 \mathrm{~g}$ and added to an Erlenmeyer flask. $20 \mathrm{~mL}$ of different solvent mixes were pouredinto the reaction container, stirring at $3000 \mathrm{rpm}$ for 30 minutes. The final solution was vacuum filtered, stored in amber flask and refrigerated for further analyses.

\subsection{Silver Nanoparticlessynthesis (AgNPs - $P$. aduncum)}

The nanoparticles metallic precursor was silver nitrate $\left(\mathrm{AgNO}_{3}\right)$ reagent grade (Scharlau, $99.8 \%$ pure), preparing $1 \mathrm{mM}$ solution and Matico ( $P$. aduncum) leaves extract as reducing agent.

In order to optimize the synthesis method, parameters were modified, considering extract amount, temperature, $\mathrm{pH}$, reaction time and metallic precursor concentration. Sodium hydroxide $(\mathrm{NaOH})$ was used as $\mathrm{pH}$ buffer.

Erlenmeyer flask with $20 \mathrm{~mL}$ of $\mathrm{AgNO}_{3} 1$ $\mathrm{mM}$ solution was heated at $60^{\circ} \mathrm{C}, 0.5 \mathrm{~mL}$ of Matico extract and $0.5 \mathrm{~mL}$ of $\mathrm{NaOH}$ were incorporated into the reaction flask. Agitation and heat were maintained for $20 \mathrm{~min}$. Final nanoparticles solution was preserved in amber flask and placed in refrigerator for further analyses.

\subsection{Silver nanoparticles characterization}

AgNPs formation were monitored with an UV-Vis Spectrophotometer (Agilent Technologies, Cary 60 model), with $10 \mathrm{~nm}$ intervals at the 350 to $800 \mathrm{~nm}$ range. Nanoparticles colloidal solution consists of a $10 \%$ dilution in distilled water.

In order to evaluate interactions between AgNPs and reducing agent active principles, a Perkin Elmer, BX FTIR model, Infrared Spectrophotometer with Attenuated Total Reflectance coupling (FTIR-ATR) was used.
Hydro-ethanolic extract $50 \%$ with AgNPs was scrutinized after $50^{\circ} \mathrm{C}$ drying treatment, obtaining characteristic spectra.

AgNPs size analysis was performed with a Scanning Transmission Electron Microscope (STEM), Tescan Mira 3 model, using nanoparticles in aqueous solution. The morphology and elemental analysis was carried out by a Scanning Transmission Electron Microscope with an Energy Dispersive X Ray (SEM-EDX) Phenom ProX with a voltage of 10 $\mathrm{kV}$. For this, the nanoparticles were dried at 70 ${ }^{\circ} \mathrm{C}$ in a heating plate.

Silver concentration in synthesized nanoparticles was achieved through a Perkin Elmer Flame Atomic Absorption Spectrophotometer (FAAS), AAnalyst 400 model, equipped with a silver hollow cathode lamp and air-acetylene flame. Results were processed using WinLab 32 software.

\subsection{Computational characterization}

The geometry optimization of the silver cluster was carried out at the B3LYP/LANL2DZ level of theory and quercetin geometry at the B3LYP/6-311G level of theory, implemented in the Gaussian 09W package of programs (Frisch, et.al., 2009). A computational modeling of silver clusters with the biological molecules was analyzed. The lower energy conformations were identified; also a study of the MO theory describing $\mathrm{HOMO}$ interactions of clusters were carried out and molecular dynamics using the Abalone program was performed to see how molecules interact for a given period of time (Abalone, 2006).

\section{RESULTS AND DISCUSSION}

\subsection{Matico leaves extract preparation}

Extracts prepared with $100 \%$ water, $100 \%$ ethanol and water/ethanol $75 \%$ were discarded due to interferences with characteristic wavelength $(417 \mathrm{~nm})$ for AgNPs during UV-Vis size monitoring.

Hydro-ethanolic extracts of 50 and $25 \%$ showed an absorption peak between 600-700 $\mathrm{nm}$, confirming no interferences with AgNPs formation peak. Afterwards, both hydroethanolic extract were applied as reducing agents in 
nanoparticle synthesis; however, 50\% mixture was selected as the more suitable extract since AgNPs formation displayed a narrow and symmetric superficial plasmon resonance peak, as well as better absorbance.

\subsection{AgNPs - P. aduncum synthesis}

Contemplating the referential values proposed by Patel et al (2015) to synthesize silver nanoparticles, optimization of synthesis parameters is presented in Table 1.

Table1. Synthesisoptimizationparameters

\begin{tabular}{c|c|c|c|c}
\hline $\begin{array}{c}\boldsymbol{P} . \\
\begin{array}{c}\text { Aduncum } \\
\text { Extract } \\
(\mathbf{m L})\end{array}\end{array}$ & $\begin{array}{c}\mathbf{T} \\
\left({ }^{\circ} \mathbf{C}\right)\end{array}$ & $\mathbf{p H}$ & $\begin{array}{c}\mathbf{t} \\
(\mathbf{m i n})\end{array}$ & $\begin{array}{c}\left.\mathbf{A g N O}_{3}\right] \\
(\mathbf{m M})\end{array}$ \\
\hline 0.5 & 45 & 5 & 10 & 0.1 \\
1.0 & 50 & 6 & 15 & 0.5 \\
1.5 & 55 & 7 & 20 & 1.0 \\
2.0 & 60 & 8 & 25 & 5.0 \\
2.5 & 65 & 9 & 30 & 10.0 \\
\hline
\end{tabular}

The first parameter optimization was $P$. aduncum extract volume, in order to evaluate reducing agent performance, maintaining $\mathrm{pH}$. Resultant colloidal solution presented an orangeyellowish brilliant appearance, containing AgNPs confirmed by UV-Vis analysis; notwithstanding, absorbance variations were detected after less than 24 hours of preparation, evidencing low nanoparticle stability.

During method optimization, successful AgNPs - $P$. aduncum in suspension were obtained, indicating a clear coloration change in the reaction process. The final color was a transparent brown-amber (Figure 1), which confirm the results presented in several studies (Fletes and Rosas, 2015). Coloration and absorbance solidness was manifested over 120 days.

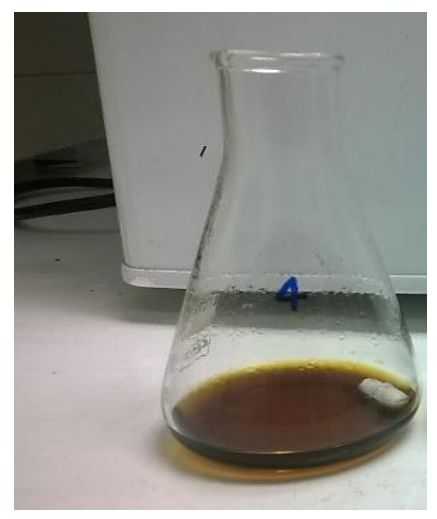

Figure 1.Stable AgNPs - P. aduncum

Synthesis conditions allow over seeing nanoparticles size, morphology, stability and aggregation. In this sense, extract amount, $\mathrm{AgNO}_{3}$ concentration, temperature, reaction time and $\mathrm{pH}$ were monitored as described by Camacho and Deschamps (2016).

Table 2 presents the optimum synthesis conditions to obtain AgNPs - $P$. aduncum at lower wavelength, getting a narrow and symmetric peak with high concentration manifested by its absorbance, corroborating extended stability in all executed reruns.

Table1.Ideal experimental synthesis conditions

\begin{tabular}{c|c}
\hline Parameter & $\begin{array}{c}\text { Optimal } \\
\text { conditions }\end{array}$ \\
\hline Extract amount $(\mathrm{mL})$ & 0.5 \\
Temperature $\left({ }^{\circ} \mathrm{C}\right)$ & 60 \\
$\mathrm{pH}$ & 9 \\
Time $(\mathrm{min})$ & 20 \\
{$\left[\mathrm{AgNO}_{3}\right](\mathrm{mM})$} & 0.1 \\
\hline
\end{tabular}

UV-Vis spectroscopy analyses disclosed AgNPs - $P$. aduncum arrangement through a characteristic peak around $400 \mathrm{~nm}$ (Figure 2), which settled nanoparticle size range between 14-35 nm according to Pradeep (2012).

At first glance, preliminary variations of synthesis parameters were depleted which were monitored by UV-Vis spectroscopy. A key factor in size and shape discern was superficial plasmon band position and profile, that exhibit UV-Vis spectra on behalf of interactions among free charge carriers and low frequency electromagnetic radiation (Rodriguez et al, 2012), bringing forth size changes as greater wavelength shifts (Ronquillo et al, 2011). 


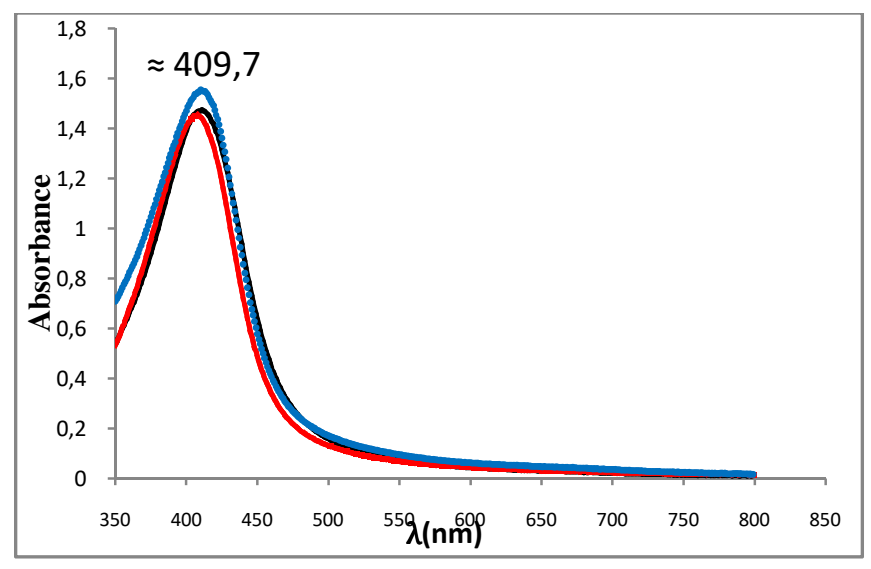

Figure 2.UV-Vis spectra of optimum AgNPs -P. aduncum synthesis

\subsection{Silver nanoparticles characterization}

It was presumed spherical or quasispherical AgNPs, due to a unique superficial plasmon resonance band, since anisotropic behavior state two or more resonance bands pursuant to nanoparticles shape (Fletes and Rosas, 2015; Camacho and Deschamps, 2016).

To settle approximate size range, results were contrasted against Pradeep (2012) reported values, demonstrating size range within 14-35 $\mathrm{nm}$. Nanoparticles size will be greater according to absorbance peak shifts to higher wavelength (Aguilar, 2009).

Results were also opposed against Shanmuga et al (2014) data; where employing Betle (Piper betle) leaves extract generate nanoparticles greater than $80 \mathrm{~nm}$ in size, presenting a maximum absorbance peak at 444 $\mathrm{nm}$.

AgNPs synthesized using black pepper (Piper nigrum) grains extract as reducing agent, form nanoparticles around $80 \mathrm{~nm}$ with a superficial plasmon resonance peak at $441 \mathrm{~nm}$ (Krishnan et al., 2016).

AgNPs - P. aduncum displayed a lower range size compared with the results previously cited, attributed to the improvement in synthesis conditions, specially the hydro-ethanolic extract matrix.

Afterwards, Scanning Transmission Electron Microscopy (STEM) was utilized to settle synthesized AgNPs size and shape. The panoramic perspective established some isolated aggregation in nanoparticles distribution; withal, some regions presented enough dispersion to be examined thoroughly (Figure 3 ).

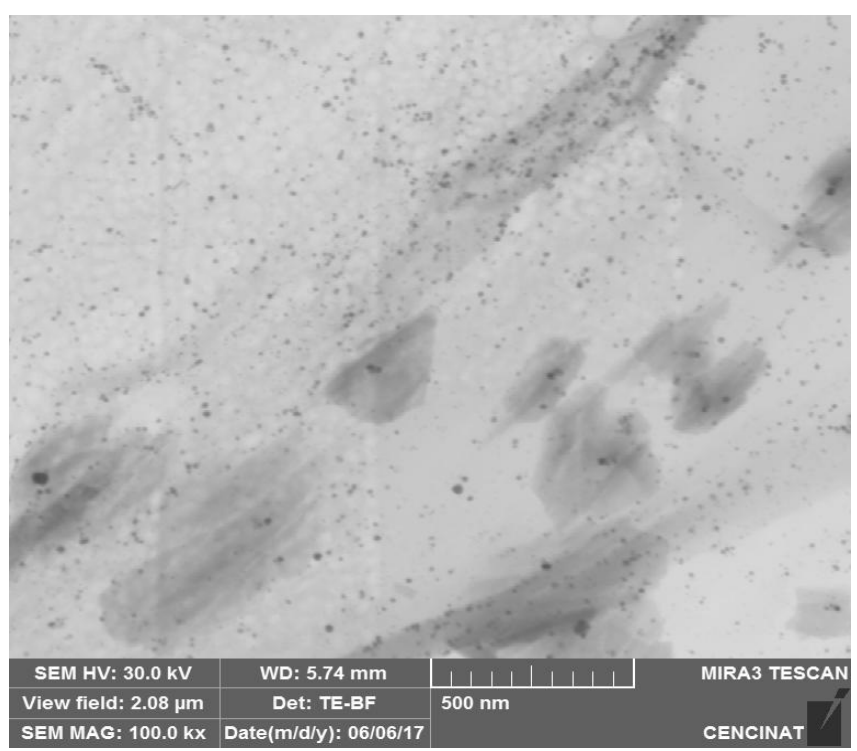

Figure 3.Panoramic micrograph AgNPs - $P$. aduncum dispersion solution (100.0 kX)

The average shape of AgNPs - $P$. aduncum is $13.58 \pm 6.25 \mathrm{~nm}$, according to Figure 4.Aggregation could be attributed to active principles remains and AgNPs interface, thus is necessary to elucidate aggregation variables.

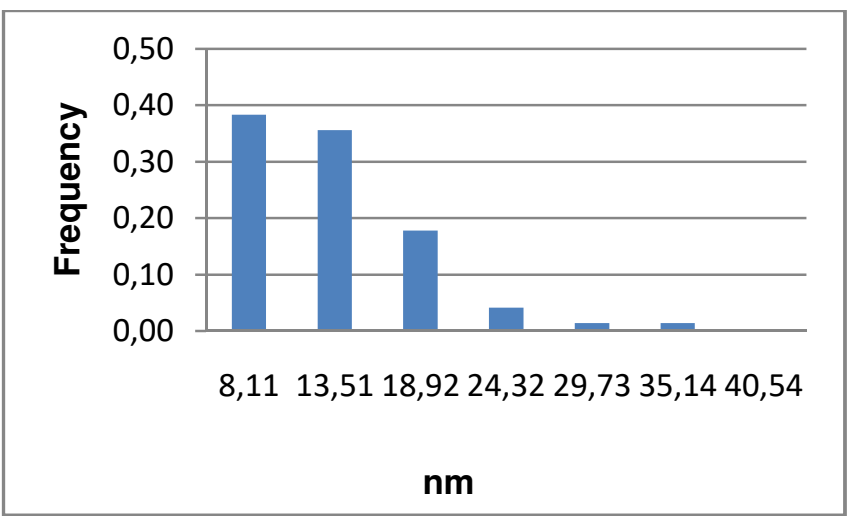

Figure 4. Histogram of average shape of AgNPs - P. aduncum

Disperse nanoparticles corroborate reducing and stabilizing influence from Matico $(P$. aduncum) hydro-ethanolic extract.

Closer and detailed overlook of AgNPs grant to estimate nanoparticle size around $20 \mathrm{~nm}$, mainly poly-disperse and some isolated aggregation layout. Nanoparticles shape corroborates UV-Vis data, suggesting quasi- 
spherical morphology (Figure 5).

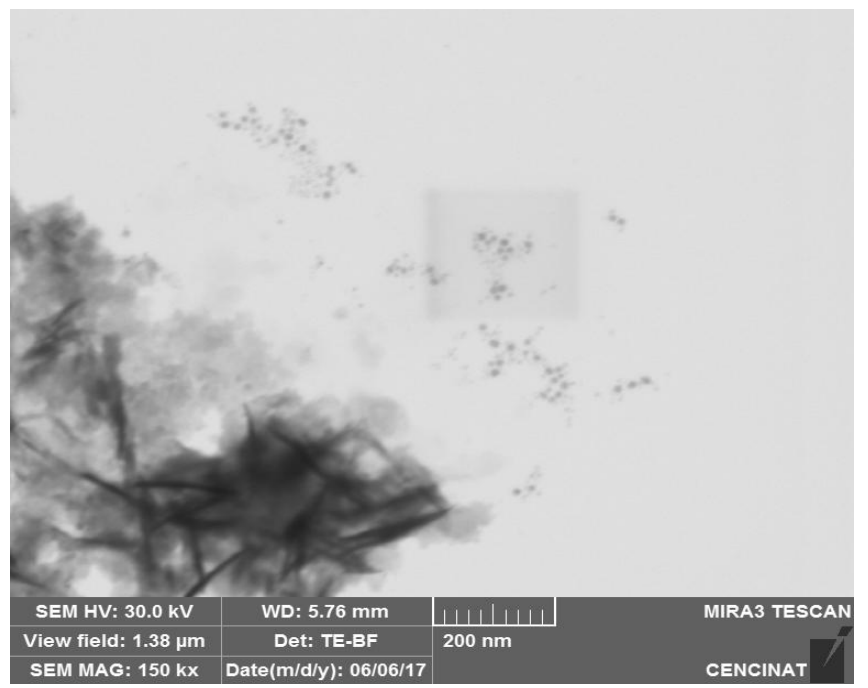

Figure 5.Isolated poly-disperse silver nanoparticles STEM micrograph (150kX)

Nanoparticles surface was analyzed by Energy Dispersive X-ray Spectroscopy (EDX). Figure 6 shows the three characteristic peaks of the silver under the $4 \mathrm{kV}$, the rest of the elements come from the other organic phyto extract.

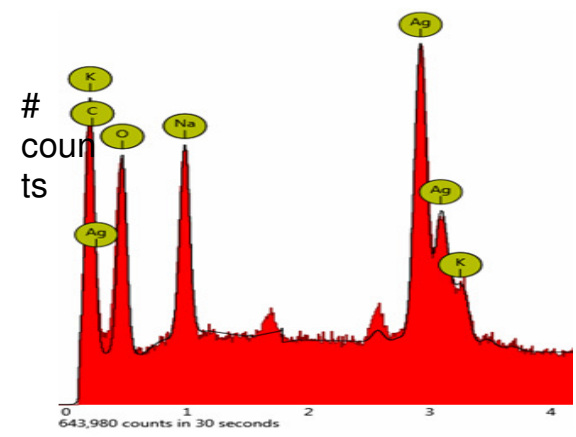

Figure 6.Nanoparticles surface composition spectra via EDX analysis. Insert: elemental detailed information (\%)

AgNPs - P. aduncum contained $7.2 \%$ of silver due to organic residue covering. Carbon $(39.2 \%)$ and oxygen (43.6\%) percentage were allocated to extract organic nature, as well as minor potassium quantity $(0.7 \%)$. Sodium concentration $(9.3 \%)$ correspond to $\mathrm{NaOH}$ pH buffer activity.

Nanoparticles surface bonding chemical species determination, likewise interactions with Matico extract, were performed by Fourier Transform Infrared Spectroscopy (FT-IR). AgNPs (a), Matico extract (b) and silver nitrate (c) FT-IR spectra were compared to correlate band behavior (Figure 7 at the end of this manuscript).

Silver nanoparticles reported low intensity band located at $2941.63 \mathrm{~cm}^{-1}$, attributed to $\mathrm{C}-\mathrm{H}$ bond torsion; another mid intensity band at $1574.11 \mathrm{~cm}^{-1}$ due to $\mathrm{C}=\mathrm{O}$ bond tension; and minor intensity band at $1360.10 \mathrm{~cm}^{-1}$, attributable to $\mathrm{N}-\mathrm{H}$ bond torsion (Figure 7.a). Nitrogen interaction bands overlapping from Matico extract spectra evince secondary amines or primary amides involvement during reduction route.

The main reducing functional groups from Matico extract correspond to acetic, mevalonic and shikimic acids due to carbonyl groups structure (Albarracin and Gallo, 2003).

Reviewing Mallikarjuna et al. (2012) work, AgNPs synthesized with Betle (Piper betle) leaves extract, characterized by FT-IR, found bands at 2920, 1640 and $1378 \mathrm{~cm}^{-1}$ as the ones obtained when Piper aduncum was employed as reducing agent.

In another study, when black pepper (Piper nigrum) grains were used, FT-IR bands appeared at 1631 and $3433 \mathrm{~cm}^{-1}$ (Garg, 2012). In this case, some differences were elucidated due to the components available in Matico extract being from the leaves.

Silver concentration in nanoparticles, as well as synthesis yield was determined by Flame Atomic Absorption Spectroscopy (FAAS). Colloidal silver concentration, $98.01 \mathrm{mg} / \mathrm{L}$ silver nitrate solution was used as reference. Final silver presence as experimental value was $101.744 \mathrm{mg} / \mathrm{L}$ with a yield of $96.68 \%$.

To define linearity, a calibration curve was constructed, with $R^{2}=0.9997$; the limit of detection (LOD) was 0.006 and the limit of quantification (LOQ) was 0,021. Fortifications were required to ascertain average recovery percentage for 1.000 and $4.000 \mathrm{mg} / \mathrm{L}$, reaching 100.61 and $98.07 \%$ respectively, with a standard deviation of 0.679 and 1.252 in each case.

In order to analyze the interaction between silver nanoparticles and the biomolecules present in the Maticoleaves, a computational modeling was carried out in order to establish the relationship between the structure and the activity of these molecules. A model 
based on few atoms was used to fulfill this purpose, due to the computational expense of modeling particles containing 50 or more silver atoms.

The interactions between quercetin and clusters of 3,5 and 6 silver atoms were studied (Figure 8). The main interaction between the silver clusters and the biological molecule is in the oxygen area, mainly in the carbonyl group. The geometries are those with the lowest energy interactions. This demonstrates that the silver nanoparticles interact with the oxygen atoms, due to their high electronegativity, and in this way, they are covered by the quercetin molecules.

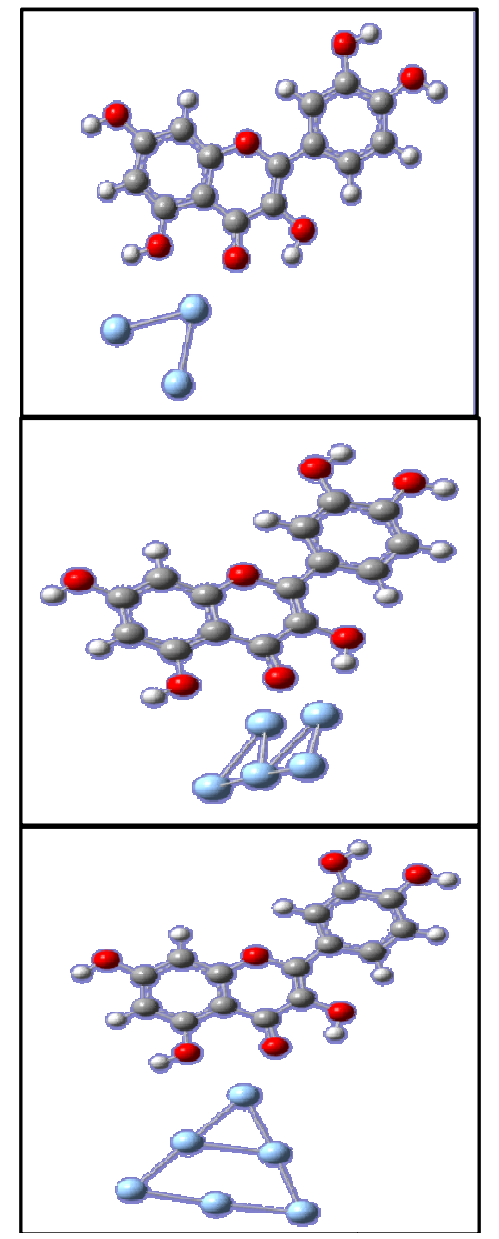

Figure 8.Interactionbetweenquercetinandthe clusters of 3, 5 and 6 silver atoms

In previous works, it was found that the main interaction was through the carboxylic acid of the lipids and the silver cluster(LanderosMartinezet.al., 2015). On the other hand, the interaction between biological molecules and silver clusters was through the hydroxyl groups as compared with the study between PVA and Ag55 nanocrystals (Chou et.al., 2014).

From the calculated interaction energies, it has been determined that the cluster with 6 silver atoms has the lowest energy and therefore could be considered the most stable.

In addition, a study of Molecular Orbital (MO)describing Highest Occupied Molecular Orbital (HOMO) interactions between the cluster and quercetin was carried out. Figure 9 illustrates the spatial and energetic properties of electrons to form orbitals. Frontier molecular orbitals have valence electrons between atoms. The shapes of the molecular orbitals showed that in the quercetin, energies are surrounded within the entire molecule (Figure 9a). However, once the silver cluster was added, the energies of molecular orbital changed and it was then located within the cluster of 6 silver atoms (b).

a)
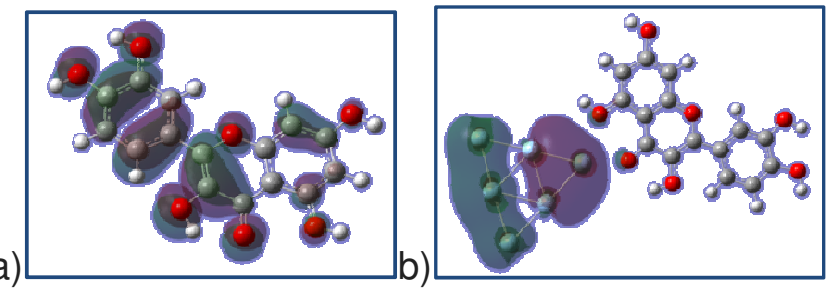

Figure 9. Interactionof HOMO surfaces between quercetin (a)and the cluster of 6 silver atoms.

Molecular dynamics is a powerful tool in molecular modeling because it gives the opportunity to follow and understand the structure and dynamics of molecules (Lindahl, 2008). Thus, Abalone program was used to simulate the natural motion of biological macromolecules, and contributed to conduct the simulations of molecular dynamics, in order to determine the interactions of biological molecules and the silver clusters for a fixed period of time: 5 and 20 ps.

The molecules were allowed to move giving a view of the dynamical evolution of the system. With different times, distances increased between the cluster and the biological molecule as indicated in Figure 10, where it is showed that the cluster did not only move far away from $2-3 \AA$ until 39.65-39.53 $\AA$, but it also moved under the biological molecule: quercetin. This meant that the cluster was moving away, (while the distances kept increasing). 


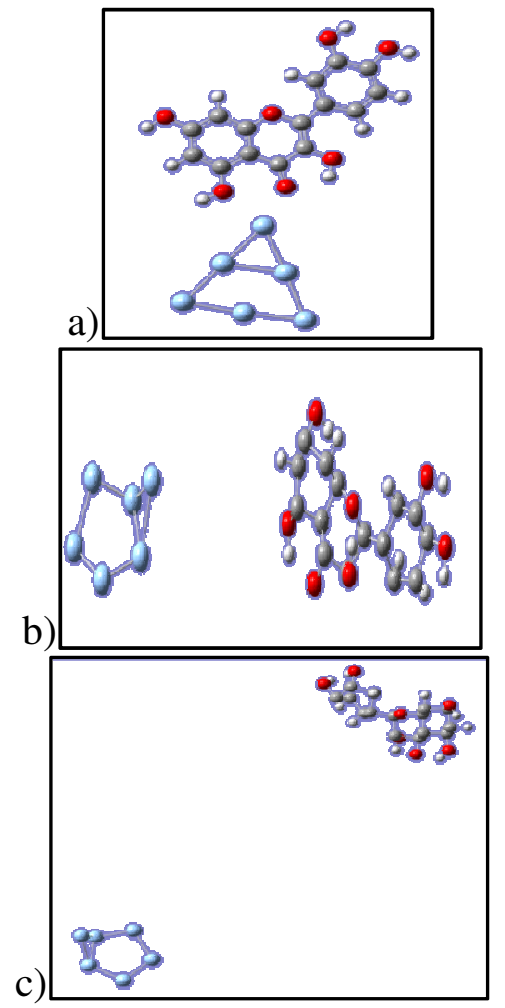

Figure10. Molecular dynamics performed at $298,15 \mathrm{~K}$. Measured distances are from the carbonyl group to the first atom of the silver cluster. Quercetin and the 6 silver cluster. No molecular dynamics2.64-2.41 ̊ (a), 5ps9.29$10.78 \AA(b)$ and 20ps39.65-39.53 $\AA$ (c)

The results illustrate that for biological molecules the cluster stay near to 5 ps which is important in the case of introducing the coated nanoparticle in an organism because the complex has to stay stable for a minimal period of time. However, at 20 ps the cluster moves far away from the biological molecules. This is really interesting because the intention is that once the coated molecule is introduced in the organism, the complex would be separated and it would be liminated in a very easy manner with optimal clearance characteristics.

\section{CONCLUSIONS}

Silver nanoparticles were synthesized using hydro-ethanolic Matico ( $P$. aduncum) extract $50 \%$ as reducing agent. This method was framed as an alternative method to obtain AgNPs in a fast, easy, economic and green chemistry alternative.

Characterization with UV-Vis spectroscopy manifested a maximum absorption peak around $409.7 \mathrm{~nm}$, defining nanoparticles size range among 14-35 $\mathrm{nm}$.STEM analyses validated prior size range, estimating AgNPs size was $\quad 13.58 \pm 6.25 \mathrm{~nm}$. Quasi-spherical, polydisperse nanoparticles with isolated aggregations were synthesized.EDX characterization determined $7.2 \%$ elemental silver, demonstrating interaction and covering up of organic extract. Additional FAAS evaluation was required to calculate colloidal silver concentration of $105.239 \mathrm{mg} / \mathrm{L}$ and a $96.68 \%$ yield. FT-IR assay, elucidated presence or band shift at $1574.11 \mathrm{~cm}^{-1}$, originating that reducing candidates from Matico could be acetic, mevalonic and shikimic acids.

The lower energies conformations were identified and the cluster of 6 silver atoms with quercetin was the most stable complex. The study of $\mathrm{MO}$ describing $\mathrm{HOMO}$ interactions of clusters contributed to find that the electronic density was around the silver cluster. Finally, molecular dynamics was performed using Abalone program to observe how silver clusters interact with biological molecules for a given period of time, 5 and 20 ps. Molecular dynamics showed that over a certain period of time the silver cluster moved far away from the biological molecule. This meant that the coated silver nanoparticles could have very good clearance properties. In future experimental work it would be interesting to do a full characterization of the coated silver nanoparticles and studies of cytotoxicity attempts for future applications.

\section{ACKNOWLEDGEMENTS}

This research was supported by project PUCE N13438 (2016-2017). Thanks to Dr. Alexis Debut from CENCINAT-ESPE for the STEM analysis.

\section{REFERENCES}

1. Agilemolecule.; ABALONE II; Program for Molecular Dinamics; Stockholm, Sweden, 2006.

2. Aguilar, M.; $P h D$ thesis, Instituto Politécnico Nacional, México. 2009.

3. Albarracín, G.; Gallo, S; $M$. Sc.thesis,Universidad Nacional de Colombia, Colombia,2003.

4. Camacho, J., Deschamps, L.;M. Sc.thesisUniversidad de Cartagena, Colombia,2016. 
5. Chou, H.; Wu, C.;Lin, F.; Rick, J.; AIP Adv, 2014,4, 087111.

6. Cruz, J.;M. Sc. thesis, Universidad Industrial de Santander, Colombia,2012.

7. Fletes, N.; Rosas, G.; Abstracts, XII encuentro de participación de la mujer en la ciencia,Mexico,2015.

8. Flores, C.; PhD thesis, Universidad Nacional de la Plata, Argentina,2014.

9. Frisch, M.J. et.al:; Gaussian 09Revision A.02. Wallingford CT.: Gaussian, Inc., 2009.

10. Garg, S.; Int. J. Innov. Biol. Chem. Sci.2012, 3, 5.

11. Hurtado, M.;B. Sc., thesis, Universidad de lasFuerzas Armadas ESPE, Ecuador. 2015.

12. Krishnan, V.; Bupesh, G.; Manikandan, E.; Thanigai, A.; Magesh, S.; Kalyanaraman, R.; Maaza, M.;J. Antimicrobial Agents, 2016, 2, 1.

13. Landeros, L.; Orrantia, E.; Flores, N.;Org. Chem. Curr. Res,2015, 4, 153.

14. Lewinski, N.; Colvin, V.; Drezek, R.; Small, 2008, 4, 26.

15. Lindahl, E.; Mol. Biol,.2008, 443, 3.

16. Mllikarjuma, K.; Dillip, G.; Narasimba, G.; Sushma, N.; Prasad, B.; Research J. of Nanotech.2012, 2, 17.

17. Patel, J.; Panchal, U.; Panchal, M.; Maykawana, B.; J. Ad. Chem. Sci.2015, 1, 82.

18. Prabhu, S.; Poulose, E.;Int. Nano Lett., 2012, 2, 32.

19. Pradeep, T.; A Textbook of Nanoscience and Nanotechnology, 1st ed., McGraw Hill: Nueva Deli, 2012.

20. Rodríguez, M.; López, J.; Herrera, V.; Orive, A.; Creus, A.;UAEM Rdalic.Org.2012, 3, 67.

21. Rongzhong, L.; Ran, C.; Pengyu, C.; Yimei, W.; PuChun, K. Cho, S.;J. Phys. Chem. B, 2013,117, 13451.

22. Ronquillo, E.; Aguilar, M.; Guzmán, J., San Martín, E.; Abstracts, XXXII Encuentro Nacional $y 1^{\text {er }}$ Congreso Internacional AMIDIQ. México. 2011.

23. Sanín, F.; B. Sc. thesis, Universidad de Guayaquil, Ecuador. 2015.
24. Santorum Y.;Ampudia S.;Pilaquinga F.; $B$. Sc.thesis,PontificiaUniversidad Católica delEcuador, Ecuador. 2017.

25. Shakeel A.;Mudasir A.;BabuLal, S.;Saiqa, I.;J. Adv. Res.2016,7, 17.

26. Shanmuga, P.; Jeyasundari, J.; Brightson, A.; Eur. Chem, 2014, 3,1014. 


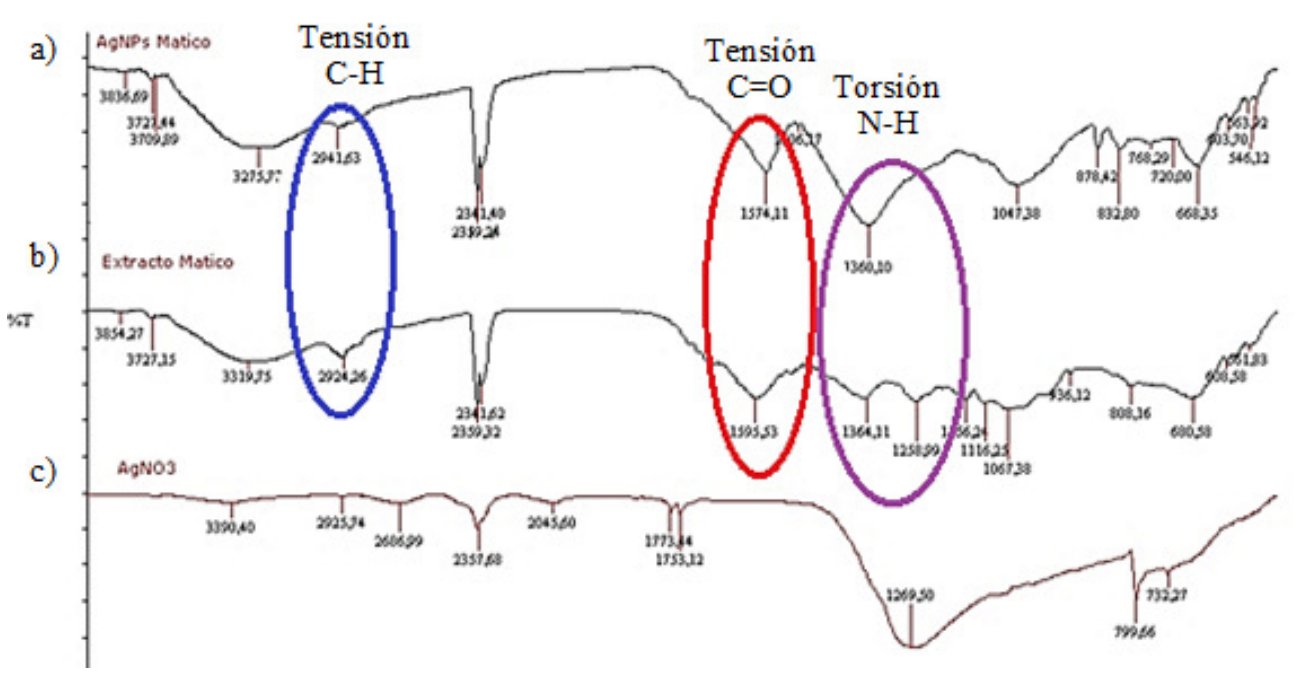

Figure 7. AgNPs (a), Matico (b) and silver nitrate (c) FT-IR spectra

PERIÓDICO TCHÊ QUÍMICA•www.periodico.tchequimica.com• Vol. 15 N. 29.

•ISSN 1806-0374 (impresso) • ISSN 1806-9827 (CD-ROM) •ISSN 2179-0302 (meio eletrônico)

The Periódico Tchê Química (ISSN: 1806-0374; 2179-0302) is an open-access journal since 2004. Journal DOI: 10.52571/PTQ. http://www.tchequimica.com. This text was introduced in this file in 2021 for compliance reasons.

(c) The Author(s)

OPEN ACCESS. This article is licensed under a Creative Commons Attribution 4.0 (CC BY 4.0) International License, which permits use, sharing, adaptation, distribution, and reproduction in any medium or format, as long as

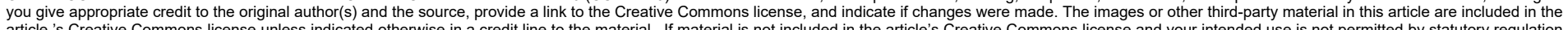
article 's Creative Commons license unless indicated otherwise in a credit line to the material. If material is not included in the article's Creative Commons license and your intended
or exceeds the permitted use, you will need to obtain permission directly from the copyright holder. To view a copy of this license, visit http://creativecommons.org/licenses/by/4.0/. 